Indonesian Journal of EFL and Linguistics

Vol. 5 No. 2, 2020

eISSN: 2503-4197, pISSN: 2527-5070

www. indonesian-efl-journal.org

\title{
Sociopragmatics Analysis of Politeness Strategy of the Main Character's Dialogues of Tinker Bell in Secret of the Wings Movie
}

\author{
Mujiono \\ Universitas Kanjuruhan Malang, East Java, Indonesia \\ e-mail: moejie_nova@unikama.ac.id \\ Afil Lailatul Ula \\ Universitas Kanjuruhan Malang, East Java, Indonesia \\ e-mail: avillaila93@gmail.com
}

\begin{abstract}
:
This study investigated the types and functions of politeness strategy used by the main character of Tinker Bell in Secret of the Wings movie. The study was a descriptive qualitative approach. The instrument of this study was document analysis. It focused on analyzing and interpreting recorded documents. To analyze the data, four interactional procedures were applied. Triangulation was used to justify the trustworthiness of data. The findings showed that the interaction between the main character and her addressee realized all politeness strategies. There were 39 data found in the conversation. Each politeness strategy's frequency was positive politeness in the first grade, with 51.3\%, followed by a bald-on record with 33.3\%. Negative politeness and 'off record' were the same positions with $7.7 \%$, \%. Second, the researchers reported two politeness strategy functions indicated by the transactional view with $74.4 \%$ and interactional view with $25.6 \%$. Last, the main character applied the politeness strategy to have a close relationship, know each other, and avoid the addressee's imposition. This politeness strategy had implications on using politeness strategies of a language in communication aspects for the community.
\end{abstract}

Keywords: politeness strategy, secret of the wings, the main character, tinker bell

Indonesian Journal of EFL and Linguistics, 5(2), 2020 


\section{INTRODUCTION}

In society, throughout human life, language has an essential role. Therefore, it reflects speakers' behaviour. As supported by (Nihayati 2018), language is a media communication for humans in their daily activity. Chaer, cited by Priscilia, Charlina, \& Rahman (2017), supports that language is a system of signs of distinctive, arbitrary speech. Human beings use it as tools of communication or social interaction. It can build human relationships. Dealing with this statement, Wang (2010) states that speakers have to choose various communicative strategies to maintain a good relationship between speaker and addressee. They also need to apply strategies to construct a good conversation.

In communication, people should use an appropriate strategy that can keep their harmony or solidarity. This strategy is also known as a politeness strategy. It is used by the speaker and addressee to keep the peace of speech. They must be aware of politeness strategy to make excellent communication; it is a way to show each other a suitable manner. Brown, P., \& Levinson (1987) explain four main types of politeness strategies; "bald on-record", "positive politeness", "negative politeness", and "off the record" (Rosari, 2017). These are important to choose to speak politely. Politeness strategy aims to make both speaker and addressee relaxed, confident, and comfortable to keep a good social relationship. Speakers should be able to choose the appropriate approach to communicate with either older people or younger ones. For instance, when the teacher speaks to a student such as "Hi Budi, what's going on?". Some people may consider it rude speech because that utterances belong to someone who closes with him/her and delivered direct expressions. It will be regarded as an appropriate talk if their conversation knows each other. Therefore, the politeness may be viewed as the medium used to indicate awareness of another person's face (Dowlatabadi, Mehri, \& Tajabadi, 2014; Ryabova, 2015).

Politeness can be found either in written or spoken language. We can discover politeness strategies in a written language such as in the novel, short story, and drama. Furthermore, in spoken words, we can find politeness strategies in daily communication, education, and movie. It takes from reality, primarily for theatre or films.

The object of this study is cartoon movies such as Tinker Bell: Secret of The Wings. It is intended to know the politeness strategy used by the main character's dialogues. Politeness is a vast area to investigate. A few previous studies concerning politeness strategies have different points of view. Ryabova (2015) has observed the politeness strategy in daily communication. This study analyzed the use of etiquette speech in some politeness forms. This investigation classified politeness in its way, focus on how people used proper etiquette in politeness strategies.

Meanwhile, Yanti (2017) observed strategies of off-record that describe implicature modesty in a conversation. This strategy explained the language usage used in direct forms. CAAT is used as a technique for analyzing the data by transcribing 
conversation back in transcription orthographic form. Putri (2017) investigated politeness strategies used by trainees in the room division department when they practised on the internship in the hotel. The politeness strategy analysis only focused on two discussions-first, the kind of politeness strategies that the trainer uses. Second, the interaction of the main character of Tinker Bell in the Secret of the Wings movie is also a communication form in which there are many linguistic phenomena. Therefore, this study related to sociopragmatic studies aimed to explain: the types, functions of politeness strategy, and the way politeness strategy is used by the main character of Tinker Bell in the Secret of the Wings movie. This study implies that sociopragmatic studies are research focused on the use of sociolinguistic. In communicating, participants are said to realize that rules are governing their actions. Sociopragmatics analysis from Tinker Bell in Secret of the Wings this movie makes us understand that each character is responsible for the actions and deviations of linguistic rules in verbal interactions.

\section{LITERATURE REVIEW}

\subsection{The Principle of Talk on Sociopragmatics Perspective}

Nurjamily (2015) states that Sociopragmatics comes from the world of sociology and pragmatics. Sociology intends to study societies and humans act in groups. In contrast, Pragmatics is considering in a particular context about what peo ple say and how it affects (Manik \& Hutagaol, 2015). Sociopragmatic is a pragmatics study that uses a standard approach (Manurung, 2010). Kasper and Rose, such as stated by (Mirzaei, A ., Roohani, A., Esmaeli, 2012) state that Sociopragmatics means sociological and pragmatic interface. It refers to the social perception underlying participants' interpretation and performance of communicative actions. Mirzaei, Roohani, and Esmaeli (2012) state that Sociopragmatics comprises the knowledge of the relationships between communicative actions and power, social inequality, and the imposition. It encompasses social conditions and consequences of what, when, and to whom you do. Sociopragmatics are used to examine the speaker's utterances and structure externally, that is, socio-cultural factors as the determinant of the statement that has spoken by the speaker.

In communicative action, the principle of talk used to succeed communication between one for another. Hymes (1996), as cited by Blackledge, Creese, \& Hu (2016), makes a group of people easy in understanding their connection by developing his speaking model. Those are setting, participant, ends, act, key, instruments, norms, and genres. An in-depth explanation of the speaking model consists of first, selecting (determines the physical circumstances, refers to the specific place and time that communication takes). Second, participants refer to who is in the conversation (takes various roles as an addressee). Psychological setting (involving the speaker and recipient of the conversation), and cultural scenes (refers to a range of formalities considered through formal, semi-formal, and informal situations). Addresses, speaker, or addressee (P1, $\mathrm{P} 2, \mathrm{P} 3)$. Third, ends refer to the purposes of the speech. And fourth, the act applies to 
the form and order or historical event. Fifth, the key relates to the spirit, tone manner of the speech act in conversation. Sixth, the instrument refers to the form or style of the speech, or we can say that it is a tool to communicate. Seventh, norms refer to norms of interacting. And eighth, genre refers to the kind of communication that is associated with speech.

\subsection{Politeness Strategy on Pragmatics Perspectives}

Pragmatics refers to the communicative competence of the speaker. It is the linguistic field dealing with rules governing the use of language in specific social contexts. It is also talking about "what to say it," "how to say it," "when to say it," and how can other people receive the language we use. In other words, it encompasses the social competency of the speaker.

The concept of politeness with pragmatics has a very closely related relationship. Brown, P., \& Levinson (1987) state that politeness is the fundamental point of pragmatics. It is the universal language usage phenomenon in a social context. The focus of Brown and the politeness theory in Levinson is the concept of face.

In line with the above statements, it can be concluded that being a polite person must abide by the rules that apply to each social relation. The speaker is impolite if the speaker violates the applicable regulations. Being polite is correctly saying something related to the public. The concept of politeness is closely related to both true and false elements of a person's attitude, measured by rules.

Leech (1983) formulates the principles of politeness into six interpersonal maxims: tact, generosity, approbation, modesty, agreement, and sympathy. This theory has been explained by Brown, P., \& Levinson (1987), which is associated with the concept of face. Experts interpret this behaviour as politeness, considering others' feelings who pay attention to a real look, the desire to be admitted and negative faces, the hope of not being freed from the burden.

\subsection{Brown and Levinson's Politeness Theory}

Brown and Levinson's theory is consisting of two parts. First, there is an idea of the essence of politeness and how it interacts. Second, three basic notions of the face theory: face, face-threatening acts (FTAs), and politeness strategies.

\subsection{Face Threatening Acts}

The face is emotionally and attended to interaction (Brown, P., \& Levinson, 1987). Brown and Levinson classified into two aspects of the face: the negative face and real face. A negative face is the individual's desire to be independent, have freedom of action, and not be imposed on by others. On the other hand, a real face is the individual's desire to be liked, admired, and approved positively. (Brown, P., \& Levinson, 1987) introduce another concept. FTAs redress the affronts to both negative and positive $\mathrm{S}$ and $\mathrm{H}$ faces in verbal exchanges (Yaqubi, Yaqubi, M., Author, C., Rose, W., Abdul, E., \& Ph, 2012). When one interacts with other people in society, it is 
necessary to avoid threatening face, whether positive or negative. To prevent these FTA's, (Brown, P., \& Levinson, 1987) propose to use strategies in the interactions to minimize the treatment depending on the participants' face risk assessment.

\subsection{Politeness Strategy}

Politeness strategies designed by (Brown, P., \& Levinson, 1987) have functioned as a regressive action to FTA (Wijayanto, Laila, Prasetyarini, \& Susiati, 2013). Brown and Levinson classified into four primary categories of politeness strategies.

\subsubsection{Bald On-record Strategy}

Lestari \& Prayitno (2016) state that bald on-record strategy is a direct way of taking something so that the addressee directly knows what is meant by the speaker. As supported by (Nihayati 2018), the speaker used this strategy because they want to express their need to the addressee. The utterance is spoken in a direct, clear, and not ambiguous. For people who know each other, they commonly found Bald on-record, and, in their environment, they are very comfortable, as well as a close friend, family, etc. Dealing with bold on record, Brown and Levinson divide into five sub-strategies; 'showing disagreement', 'giving suggestions', 'requesting', 'warning', and using the 'imperative form'.

\subsubsection{Positive Politeness Strategy}

Brown and Levinson's theory explains that a positive politeness is approached-based and tries to show that $\mathrm{S}$ wants H's desire. (Karimkhanlooei \& Vaezi, 2017) declare that positive politeness is used to minimize threat addressee's positive face by imagining that the speaker and addressee have the same background or having close relationship friends. The speaker used it when they want to positively appreciate the speaker by using solidarity utterance to keep harmony between speaker and addressee. (Achmad, 2012). In a group of friends or where people know each other often saw this in the given social situation. Positive Politeness strategies usually try to minimize FTA. Besides, positive politeness is not only useful for minimizing FTA, but also in general. When $\mathrm{S}$ uses them, it indicates he/she wants to come closer with $\mathrm{H}$. Sub strategies included in positive politeness can be identified into three; claiming common ground, expressing cooperation, and attending to addresses desire (Karimkhanlooei \& Vaezi, 2017).

\subsubsection{Negative Politeness Strategy}

Negative Politeness is oriented to the H's negative side and focuses on preventing the hearer from imposing. (Rosari, 2016) state that negative culture is "the heart of respect behavior," which means that it performs minimizing particular impositions function on the hearers. To reduce the impositions, a speaker may use hedges and convey pessimism in the utterances. (Brown, P., \& Levinson, 1987) mention that a negative politeness strategy aims to create distance between the speakers and the hearer to show respect behaviour. They classify five sub-strategies of negative politeness strategy: 
indirect, not presuming/assuming, not coercing $\mathrm{H}$, communicating $\mathrm{S}$ 's desire to not intrude on $\mathrm{H}$, and redressing others' desires.

\subsubsection{Off-Record Strategy}

(Niroomand, 2012) declares that 'off the record' is a strategy where the speaker used ambiguous or unclear utterances that the addressee infers the intended meaning. However, off-record using indirect utterance should interpret the meaning of the language. Off record utterance usually uses indirect language that constructs more general utterance or different from what someone means. (Brown, P., \& Levinson, 1987) have also explained some sub-strategies of off the record. They classify into two; (a) inviting conversational implicature (giving hint, presupposing, giving association clues, understating, overstating, using tautologies, using metaphor, using contradictions, being ironic, and using rhetorical questions and (b) being vague or ambiguous: violating the manner maxim (being ambiguous, being unsure, overgeneralizing, displacing $\mathrm{H}$, and using ellipsis).

\subsection{The function of Politeness Strategy}

Politeness strategy is as language usage, which talks in situations and phenomena in social interaction. However, Brown \& Yule (1983) classify it into two terms; (1) transactional view; (2) interactional view.

\subsubsection{Transactional View}

Linguists and the philosophy of language believe that delivering knowledge is an essential aspect. Transactional language is the language to express or proportionally communicate factual information. The principal transnational language is the efficient transmission of information-language used for conditions like message-oriented. The speaker has to give the expression. Unless they could not interpret the message correctly, the effects would not be satisfying in the real world (Brown, P., \& Levinson, 1987).

Language function in the transaction perspective has a function represented by the opinions expressed (Lyons, 1996). Concerning language functions, the word given with a simple and straightforward definition in this context does not cause the expression to be multi-interpreted. In conclusion, the transaction view is the language function to reveal the information.

Transactional communication emphasizes sending and receiving messages conducted on an ongoing basis in an episode of communication. Communication is a process of cooperative transactions in nature, i.e., the sender and recipient are equally responsible for the impact and effectiveness of communication. It requires between speaker and addressee to be aware of the effects of a message toward another message. And it assumes that when we are continually sending and receiving messages. In other words, the participants in communication affect the process of negotiating the meaning. 


\subsubsection{Interactional View}

Language interactional views see language as a medium to build and maintain interpersonal relationships and act social transactions between speaker and addressee (Brown \& Yule,1983). Two persons in a room, for example. One of them opened the conversation, "hot room temperature.". The speech is not intended as information but as a fun and relaxed conversation. The interactional conversation focuses on the process of two-directional communication done by the speaker and the addressee (Schramm, 1997). It has shown that communication will always arise. One of the essential elements of interactional conversation is feedback or response to the message (Richard \& Lynn, 2018).

\section{RESEARCH METHODOLOGY}

\subsection{Source of the Data}

The research data were dialogues of Tinker Bell as the main characters in "Tinker Bell: Secret of The Wings" movie whose utterances containing politeness strategies. The data of the study were linguistic units that exist in the Secret of the Wings. The Tinker Bell in Secret of The Wings Movie is addressed for all ages and deals with cheerful and funny. The film tells the story of Tinker Bell and the fairy in the winter, and the forest fairy in winter that remains a mysterious and forbidden place. Warm and cold fairies are unable to cross into each other's nature to avoid the risk of brittle limbs of their wings. Tinker Bell sneaks across the border into winter, and something extraordinary happens, its wings begin to sparkle and shine. Tinker Bell searches for an explanation and then meets Periwinkle, an ice fairy whose own wings sparkle and shine. With the help of wise old fairies, Tink and Peri find them by establishing an excellent friendship. And when the terrifying frozen season threatens to destroy the Pixie Dust Tree, they unite to see whether they can save their world

\subsection{Instruments}

Bogdan, R.C. \& Biklen (1982) explains that the nature of qualitative research has a natural setting as a direct database. The researcher himself is the principal instrument in this analysis. The scientist is the critical resource that indicates that the researcher was the principle instrument for the analysis. He was able to direct the raw data collection process from the beginning to the conclusion.

However, the secondary instrument from the research is document analysis. According to (Ary, D. Jacobs, L. C., \& Sorensen, 2010), document analysis focuses on analyzing and interpreting printed or recorded documents. However, document analysis requires the data to be examined and understood to elicit meaning, understand, and develop empirical knowledge.

As sources of data, the document has various forms, such as printed materials such as textbooks, newspapers, novels, script, or recorded material such as documentary film, movie, and any other types of recordings. The researcher used the movie script of Tinker Bell: Secret of The Wings as the document. From the record, the researcher 
classifies the utterance of politeness strategy by using document analysis based on Brown \& Levinson's theory (1987).

\subsection{Data Analysis Procedures \\ 3.3.1 Data Reduction}

The researcher took several ways to organize the data from some sources that were supposed to be sorted and focused on this research object. The researcher watched the film several times to mark the utterances that belong to the politeness strategy. The script of Tinker Bell: Secret of The Wings used to focus on identifying Tinker Bell's conversation. The researchers eliminated the dialogue, which does not consist of Tinker Bell and Tinker Bell's monologue. Afterwards, the researcher gives code for the data only based on the application of politeness strategies in Tinker Bell's conversation. The data will be transferred into the sheet to code of each information as the following table 1.

Figure 1: Code of Politeness Strategy data by the main character in Tinker Bell: Secret of the Wings.

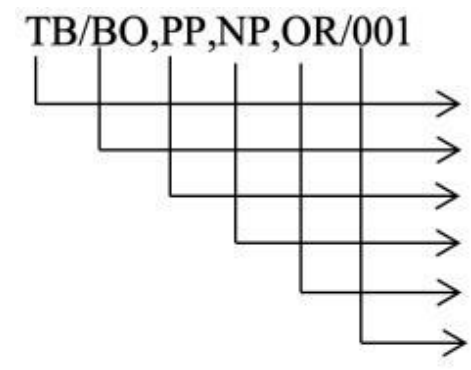

\section{Tinker Bell (Name of character) \\ Bald On-Record, Positive Politeness, Negative politeness, Off the record Number of data}

\subsubsection{Data Display}

The second step of the analysis was to show the result of the question already answered by theories. The researcher displayed three points; (1) the type of politeness strategy used in Tinker Bell's dialogue, (2) recognizing its function, and (3) how the main character used politeness strategies in her dialogues. In the first point, the researcher displayed a type of politeness by showing the data percentage. For the second point, the percentage used to explain and to show the function of politeness strategy. The last one was how the main character applied the politeness strategy. The utterance could be a phrase or sentence that Tinker Bell delivered to another character. The observation was applied to know the context of the data. And the descriptive strategy was applied to explain the politeness strategy used in Tinker Bell's utterance in that movie.

\subsubsection{Data Verification}

The data verification was needed to ensure that no missing and error data. The researcher conducted several steps to analyze the collected data. Creswell (2007) states that the researcher needs to understand the text or image to answer the research problem. Analysis of research data is carried out in various ways; (1) reviewing collected data, (2) coding each data, (3) dividing the data based on politeness 
application in Tinker Bell's conversation, (4) determining the function of using politeness strategies in Tinker Bell's conversation, (5) concluding the result.

\subsection{Triangulation}

To check data's trustworthiness, triangulation was applied (Ndanu, Mwaniki Celestine \& Syombua, 2015). The researchers triangulated among different data sources to enhance the accuracy and validity of their study Creswell (, 2007). The application of source data and theoretical triangulations was intended to find and interpret relevant data with dialogue. Expert judgment was used to avoid a mistake resulting from the study and to examine the data trustworthiness.

\section{FINDINGS}

\subsection{Types of Politeness Strategy}

Table 2 showed 13 data of 'bald on-record', 20 data of 'positive Politeness', 3 data of 'negative politeness', and 3 data of 'off record' from the main character in Tinker Bell: Secret of the Wings. Percentage of Type of Politeness Strategy and sub-strategies can be presented in table 1 .

Table 1: Type of Politeness Strategy and sub-strategies the main character in Tinker Bell:

The Secret of the Wings

\begin{tabular}{|c|c|c|c|c|c|c|}
\hline No & Politeness Strategies & Sub Strategies & $\sum$ data & $\%$ & $\mathbf{N}$ & $\%$ \\
\hline \multirow[t]{4}{*}{1} & Bold on Record & Showing Disagreement & 3 & 7.69 & 13 & 33.3 \\
\hline & & Using Imperative Form & 7 & 17.94 & & \\
\hline & & Giving Advice/suggestion & 2 & 5.12 & & \\
\hline & & Requesting & 1 & 2.56 & & \\
\hline \multirow[t]{8}{*}{2} & Positive Politeness & Offering something to $\mathrm{H}$ & 1 & 2.56 & 20 & 51.3 \\
\hline & & Using in Group Identity Marker & 4 & 10.25 & & \\
\hline & & Avoiding Disagreement & 2 & 5.12 & & \\
\hline & & Slang & 1 & 2.56 & & \\
\hline & & Exaggerating & 2 & 5.12 & & \\
\hline & & Including both $\mathrm{S}$ and $\mathrm{H}$ in the activity & 8 & 20.51 & & \\
\hline & & Repetition & 1 & 2.56 & & \\
\hline & & Seek Agreement & 1 & 2.56 & & \\
\hline \multirow[t]{2}{*}{3} & Negative Politeness & Apologizing & 2 & 5.12 & 3 & 7.7 \\
\hline & & Be indirect & 1 & 2.56 & & \\
\hline \multirow[t]{2}{*}{4} & Off Record & Being incomplete & 3 & 7.69 & 3 & 7.7 \\
\hline & Total & & 39 & 100 & 39 & 100 \\
\hline
\end{tabular}


Mujiono \& Afil Lailatul Ula

Chart 1: Type of politeness strategy

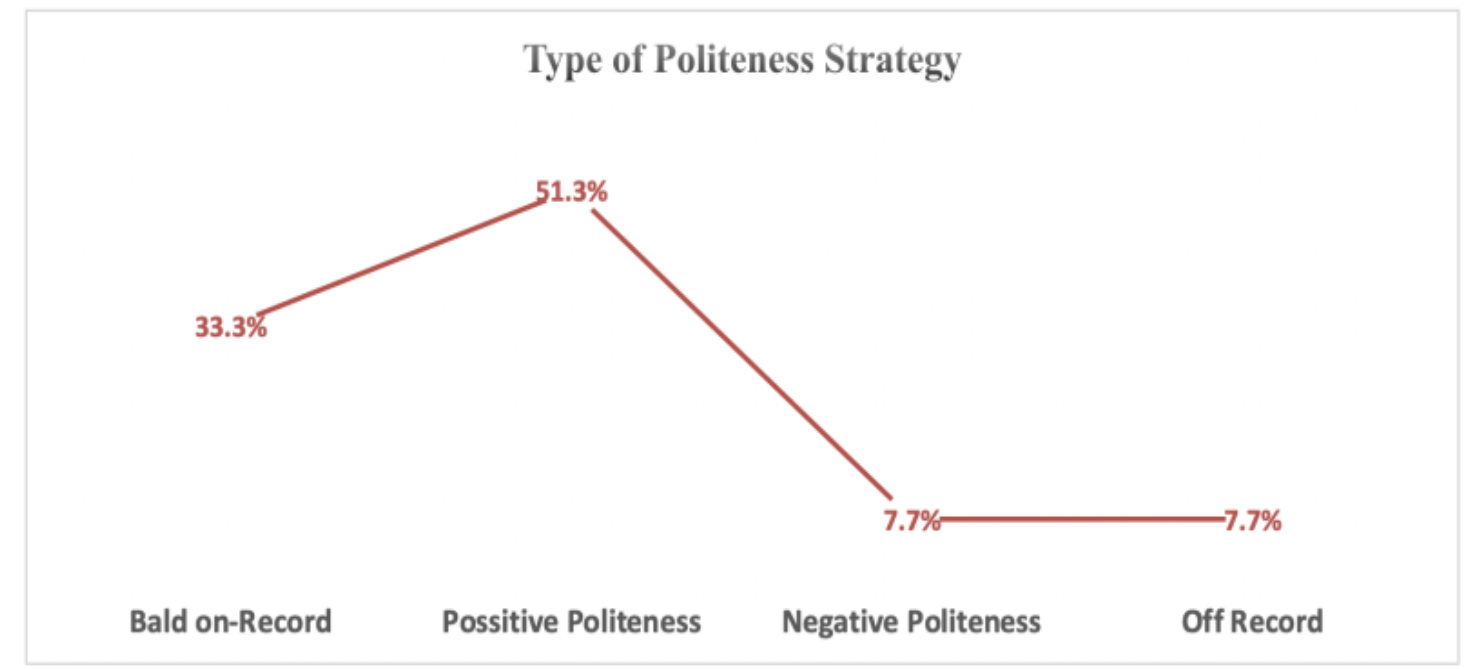

Based on the chart above showed that the highest frequency in the tinker bell's utterances was bald on-record, 33.3\%, 51.3 of positive politeness. Meanwhile, negative politeness and off record have the same frequency, $7.7 \%$. The following data was one example of data from each politeness strategy and sub-politeness strategies on the main character in Tinker Bell: Secret of the Wings.

\subsubsection{Bald On-Record}

The findings reported that there was four (4) type of sub-strategies of bald on-record. These sub-strategies were showing disagreement, using the imperative form, giving suggestions, and requesting. The following data explained one example of data that indicated bald on-record of each sub-strategy.

\subsubsection{Showing Disagreement}

\section{Extract 1}

Iridessa: But you heard her. It was just the light reflecting off the snow.

Tinker Bell: No, it wasn't. They lit up. It was brighter than a thousand fireflies. You saw it. Didn't you, Fawn?

Fawn: No.

Excerpt 1 showed that speakers Iridessa and Fawn did not believe in the addressee, Tinker Bell, about the sparkled wings. Tinker Bell replied, "no, it wasn't," to show her disagreement with her friends. She wanted her friend sure that her sparking arms. The data extract 1 showed that the addressee wanted to prove to speakers that her statement was right. She put it in a negative face, as shown in bold and italicized words inline 3 . In this conversation, Tinker Bell used bald on-record by putting a negative face. 


\subsubsection{Using Imperative Form}

Extract 2

\section{Periwinkle: The Autumn Woods. \\ Tinker Bell: The freeze. It's moving so fast. Come on! We have to get to the tree!}

The data excerpt 2 showed that the speaker wanted to prove to the addressee that she wished to the addressee to get attention. She put it negative face and used bald onrecord, as shown in bold and italicized words inline 2-3. In this conversation, the speaker used bald on-record by putting a negative face.

\subsubsection{Giving Suggestion}

Extract 3

Tinker Bell: It's getting warmer, you should get back to winter.

Periwinkle: Yeah.

The data extract 3 showed that Tinker Bell showed her broken wings to the other. Like her sister, Periwinkle sad with Tinker Bell's condition. As the weather got warmer, Tinker Bell asked Periwinkle to return home. Tinker Bell used bald on-record to advise Periwinkle by putting a negative face. The data excerpt 3 showed that the speaker wanted to show her care to Periwinkle. She put it negative face and used bald on-record, as shown in bold and italicized words inline 1-2. In this conversation, the speaker used bald on-record by giving suggestions.

\subsubsection{Requesting}

Extract 4

Tinker Bell: Okey. Here's the plan. Meet me here tomorrow!

Periwinkle: Oh, thank goodness. I thought you were saying goodbye.

Excerpt 4 showed that speaker, Tinker Bell, and addressee, Periwinkle was a sister who never met before. When they wanted to be together, they could not do it because they lived in different seasons. Tinker Bell had a plan to invite Periwinkle to pixie hollow. She put it in a negative face, as shown in bold and italicized words inline 1 . She used bald on-record by requesting to ask her sister to meet her in the border.

\subsubsection{Positive Politeness}

These findings showed six sub-strategies of positive politeness. They offered something to $\mathrm{H}$, using in group Identity marker, avoiding agreement, slang, exaggerating, including both $\mathrm{S}$ and $\mathrm{H}$ in the activity, repetition, and seek agreement. 
The following data explained the examples of data that indicated the positive politeness of each sub-strategy.

\subsubsection{Offering Something to $H$}

Extract 5

Tinker Bell: Oh, you're taking the animals today?

Fawn: Trying to. It's time for them to cross the border, but this little guy is a handful. Tinker Bell: Hey, uh, how about if I help?

The data extract 5 showed that Tinker Bell wanted to know, and she was interested in winter woods. When she heard Fawn wanted to take an animal into winter woods, Tinker Bell offered Fawn help to know the winter woods. She put a positive face when she provided support to the addressee. For this data, the researcher only found one data that indicates offering something to $\mathrm{H}$.

\subsubsection{Using in-group identity marker}

Extract 6

Fawn: Thanks, Tink.

Tinker Bell: No problem, Fawn.

Dewey: Yes! And your wings are identical. That is why they sparkle.

Tinker Bell \& Periwinkle : Jingles!

Dewey: $\quad$ Ah... Oh, boy. Maybe you shouldn't do that.

The data excerpt 6 showed that the speaker claimed an in-group identity marker with her addressee. For instance, the word "Fawn." used positive politeness, as shown in bold and italicized words inline 2. In this conversation, the speaker used positive politeness by using an in-group identity marker. It was the first time Tinker Bell met with her sister, Periwinkle. Dewey showed them how they could separate each other and proofed them that their wings were identical. In this situation, Tinker Bell used slang "Jingle" to state that she was shocked by something. Tinker Bell and Periwinkle had their language to express their shock.

\subsubsection{Avoiding Disagreement}

Extract 7

Clank: Tink! Wait!

Bobble: You can't cross the border, Miss Bell.

Your wings!

Tinker Bell: Don't worry. They're in my coat.

The excerpt 7 showed that speakers Tinker Bell wanted to know about the sparkling wings; she decided to go to the winter woods. Her friends tried to warn Tinker Bell about the wings, which could not touch the cold weather. Tinker Bell convinced them that her wings would be deliciated by using positive politeness. The speaker wanted to 
avoid disagreement with the addressee. She put it negative face and used positive politeness shown in bold and italicized words inline 3 . In this conversation, the speaker used positive politeness by avoiding disagreement.

\subsubsection{Slang}

\section{Extract 8}

Tinker Bell \& Periwinkle (both): Jingles! (both laugh)

Dewey: That's a new chapter.

Fairy Mary: Oh! Queen Clarion!

Dewey: I didn't know they were going to do the smoochy, smoochy. Guess they're telling people now.

The data excerpt 8 showed that this is the first Tinker bell meet with her sister, Periwinkle. Dewey shows them how they can separate each other and proof them that their wings are identical. In here situation, Tinkerbell uses the slang "Jingle" to state that she shocks with something. Tinker Bell and Periwinkle have their language to express their shock.

\subsubsection{Exaggerating}

\section{Extract 9}

Fawn: Just tell us what to do.

Tinker Bell: Great! Okay. We need to place that wheel right here.

The data excerpt 9 showed that Tinker Bell had a plan to take Periwinkle to the Pixie Hollow. Tinker Bell, Clank, and Bobble made an ice maker for Periwinkle. Clank invited Vidia and the other to help Tinker Bell. Tinker Bell was excited when her friends wanted to help her. She said "Great" because she thought it was fascinating when her friends tried to help her and work together to make icemakers. The excerpt 9 showed that the speaker wanted to give the word stressing, such as the word "Great." She used positive politeness shown in bold and italicized words inline 2 . In this conversation, the speaker used positive politeness by exaggerating.

\subsubsection{Including both $S$ and $H$ in the activity}

\section{Extract 10}

Tinker Bell: And let's get that propped up over there.

Rosetta: I feel so, Thinkery.

The data excerpt 10 showed that Tinker Bell wanted to invite Periwinkle in the Pixie Hollow. Therefore, she made an ice maker for Periwinkle to protect her wings from warm weather. She was pleased when her friends went to Tinker's nook and wanted to help her. Tinker Bell asked her friend to finish ice maker together, which meant they 
were in the same activity. When she said, "Let's," it meant that she invited someone to do something with her.

\subsubsection{Repetition}

\section{Extract 11}

Tinker Bell: There's no time. Clank, grab some ice. We'll wrap her wings.

Tinker Bell: Be careful. Gentle. Easy.

Tinker Bell: Okay. Let's go. Hurry!

Clank: All together. All together.

Rosetta: All together.

Silver mist: Hurry!

Iridessa: Come on! We can do this!

Fawn: Hurry!

Bobble: Go, go, go!

The excerpt 11 showed that Tinker bell was confused and worried about her sister because the ice maker is run out of ice. However, Tinker bell gives first aid by wrapping the wings with the ice. Tinker Bell uses repetition like "Be careful. Gentle. Easy" to emphasize that her friend should be careful about Periwinkle. Although the words are different, they have the same meaning: being calm intake care Periwinkle.

\subsubsection{Seek Agreement}

\section{Extract 12}

Tinker Bell: Please, can you help her?

Vidia: Tink.

Lord Milori: Gently. Lift your wings. Let the cold surround them.

Tinker Bell: You're okay. Your wings are okay.

Periwinkle: Yeah. Yeah.

Lord Milori: This is why we do not cross the border.

Periwinkle: No, it could've worked! We just needed a more significant piece of ice.

The data excerpt 12 showed that Fairy wings are starting to regain their shimmer and colour. He tries to vibrate and sighs with relief as they work. Tinker Bell very happy when she knows her sister began to fly again. She uses repetition to make sure that Peri's condition is excellent.

\subsubsection{Negative Politeness}

The finding showed two (2) sub-strategies of negative politeness; apologizing and being indirect. The following data explained one example of data that indicated negative politeness of each sub-strategy. 


\title{
4.1.3.1 Apologizing
}

\author{
Extract 13
}

(Again, the fairy with glasses shot Tink a warning look)

Tinker Bell: Sorry. Found it!

The excerpt 13 showed that Tinker Bell looked for the information about the sparkle wings in the book nook. She made some noise because of the wing ology book was flew everywhere. The reading fairy warned Tinker Bell to be quiet. For the Tinker Bell mistake, she asked for her forgiveness because she has already made some noise in the book nook where there is no fairy allowed to make some noise.

\subsubsection{Being Indirect}

\section{Extract 14}

\section{Tinker Bell: Hey. Do you know anything about the sparkling wings?}

Reading Fairy: No. The bookworm ate the page.

The data excerpt 14 showed that Tinker Bell looked for information about the sparkle wings in the book nook. Finally, she found the book that the contents are all about the wings. Unfortunately, the important page that explains the sparkle wings has eaten by the bookworm. In her utterance, "Do you know anything about the sparkling wings?" she stated it by being conventionally indirect and also put negative face to make her more polite because she already made little noise in the book nook. The researcher only found one datum that indicates be indirect sub-strategy in this movie.

\subsubsection{Off Record}

This study reported one (1) sub-strategy of off record. It was incomplete. The following data explained one example of data that indicated sub-strategy of off record.

\subsubsection{Being Incomplete}

\section{Extract 15}

Fawn: They're freezing! We'd better get you to a healing-talent fairy. Tinker Bell: But ...

The data excerpt 15 showed that while Fawn still busy with the marmot, Tinker Bell wanted to see what winter like was. She jumped over the border. Tink shivered. But the snow was magnificent. Tinker Bell felt a tremendous sensation on his wings all at once. She turned herself back with a gasp. The wings look shiny. Her wings shimmer with a brilliant beam of light that she has never witnessed before. Suddenly, Fawn pulls Tinker Bell back over the border to autumn. She wanted to explain her sparkle wings, but Fawn did not care about her story. That is why Tinker Bell used an uncomplete sentence because her utterance was cut off by Fawn who worried about Tink's wings. 


\subsection{The Function of Politeness Strategy}

The study reported that there was two (2) function of politeness strategy types. Table 2 showed that 26 data belongs to a transactional view and 12 data for the interactional view. The percentage of the function of Politeness Strategy can be seen in chart 2.

Percentage of the function of Politeness Strategy and sub-strategies can be presented in chart 2.

Chart 2: Function of Politeness Strategy

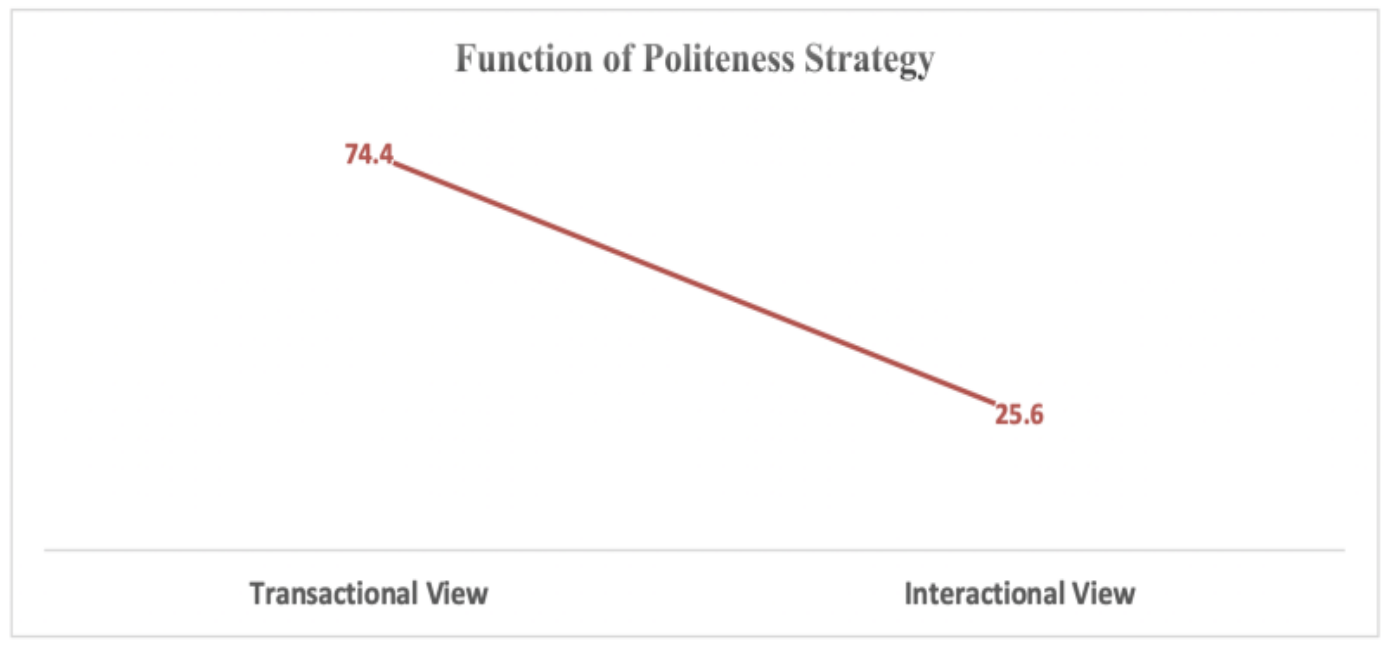

Chart 2 showed that $74.4 \%$ of data belongs to a transactional view and $25.6 \%$ of the interactional view. The following data was two (2) example of data from each the function of politeness strategy on the main character in Tinker Bell: Secret of the Wings.

\subsubsection{Transactional View}

\section{Extract 16}

Tinker Bell: Okay. Here's the plan. Meet me here tomorrow.

Periwinkle: Oh, thank goodness. I thought you were saying goodbye.

Tinker Bell: No! I just met my sister I never knew I had, and I'm going to say goodbye forever? Are you kidding? So...

Tinker Bell: Clank? Bobble?

Tinker Bell: Guys?

The excerpt 16 showed that Tinker Bell gives understanding to Lord Milory that she does not want to be separated by her sister, Periwinkle. It is related to the transactional view that the speaker provides information to address. 


\section{Extract 17}

Tinker Bell: It's getting warmer, you should get back to winter. Periwinkle: Yeah

(But she couldn't let go. She turns to leave. She turns around and looked at her) Tinker Bell: Hey. I'll be okay. I'll meet you tomorrow at the border. Sisters? Periwinkle: Sisters.

The excerpt 17, line 1, took place at the pixie dust tree- the conversation practised by Tinker Bell and Periwinkle. Based on the example of data excerpts displayed above, as shown in bold and italicized words, they talked about the weather in Pixie Hollow. It was getting warmer, and Tink asked Periwinkle to get back to the winter. It meant that Tinker Bell gave the addressee information for following what she had said because it was essential for Periwinkle's life. A data excerpt was displayed in the following data, as shown in the bold and italicized form.l

\subsubsection{Interactional View}

Extract 18

Rosetta: Look at that!

Tinker Bell: It's frost. She and her friends practice in the Frost Forest. You should see it!

Periwinkle: Oh, you should see Tink on ice skates. (Chuckles) She's a natural.

Tinker Bell: It's because you had that lost thing.

The excerpt 18 showed that Tinker Bell tries to have a chit chat with her friends because she wants to build a good relationship between Peri Winkle and her friends.

Extract 19

Fawn: Just tell us what to do.

Tinker Bell: Great! Okay. We need to place that wheel right here.

Iridessa: Got you, Tink.

Tinker Bell: And let's get that propped up over there.

Rosetta: I feel so Tinker.

Tinker Bell: Clank, Bobble...

Bobble: Wait, wait. Finish up the chassis?

Tinker Bell: Exactly.

The data excerpt 19, line 2, took place at the Tinker Bell's nook. Tinker Bell and Fawn practiced the conversation. Based on the example of data excerpts was displayed above, as shown in bold and italicized words, this part told that Tinker Bell happy when her friend wanted to help her for making an ice maker. Tinker Bell said it was to give thanks to her friend for their help, and she made social relationships better.

\section{DISCUSSION}

The findings reported four (4) politeness strategies and fifteen (15) politeness substrategies used by the main character in Tinker Bell: Secret of the movie. Four (4) 
politeness strategies are bold on-record, positive politeness strategy, negative politeness, and off record (Brown, P., \& Levinson, 1987). Sub-strategy for bold onrecord includes showing argument, using the imperative form, giving advice/suggestion, and requesting. Positive politeness consisted of offering $\mathrm{H}$, using in-group identity marker, avoiding agreement, slang, exaggerating, including both $\mathrm{S}$ and $\mathrm{H}$ in the activity, repetition, and seek agreement. Negative politeness includes apologizing and be indirect. And off record includes being incomplete. Here were the detailed sub-strategies of politeness used by the main character in Tinker Bell: Secret of the movie.

\subsection{Type of Politeness Strategy}

\subsubsection{Bald on-Record}

The main character used four sub-strategy from five sub-strategies of bald on-record, showing disagreement, giving suggestions/advice, requesting, and using the imperative form. This strategy is a direct action that tends to be command-free (Cutting, 2002). The aim of the speaker used this strategy was to minimize the FTA to the addressee. The FTA can be very low when the speaker used bald on-record to request, offer, or give advice sub-strategy (Tobing, 2017). The tendency to use bald on-record was due to the videos' nature to use direct languages. Based on Brown, P., \& Levinson (1987), the strategy of saying a speech can also be done bald on-record (explicitly) which is to speak directly what it means. The bald on-record goal is not to minimize the threat to the face of the interlocutors' face. This strategy directly leads others to express their needs (Adel, Davoudi, \& Ramezanzadeh, 2016). The main character used bald onrecord under certain conditions. Bald on-record was, used because between the speaker and the opponent, speech already knows each other. The most frequently sub-strategies of bald on-record was using the imperative form.

The main character always used this sub-strategy because she knew that She and her addressee were urgent.

\subsubsection{Positive Strategy}

The most dominant politeness strategy used by the main character was Positive Politeness. A few reasons for using positive politeness by the main character were apologizing and describing how characters expressed their apologies. Elham, Farinas Shirani, \& Hadi (2016) have investigated kinds of offenses in Politeness Strategy in "Revolutionary Road" to deliver their apologies and describe how characters expressed their apologies. He Implemented Holmes's theory to analyze the main characters in the film. He started to investigate the apology's utterance in the movie's character after collecting data and classified it into the type. The preference for applying this strategy was related to the relationship between the main character and her friends. Using the politeness strategy, maybe because of the speaker's closeness and the addressee (Adel et al., 2016). The states that when someone says to the person whom he knew better, the politeness strategy usually appears in this condition (Adel et al., 2016). However, this politeness strategy indicates that both speakers and the addressee are the same set 
of people sharing specific wants, purposes, and values. The main character used a positive politeness strategy to show his greater interest, sympathy, compliment, and an excellent relationship to the addressee. This strategy is appropriate with the theory of Brown, P., \& Levinson (1987) if the use of group identity marker means that the speaker and addressee have a good relationship (Wijayanto et al., 2013). This theory claim that the speaker is the same as the addressee in a group or community. Choosing positive politeness because she wanted to establish a good relationship with people around or friends. Abbas (2013) also declares that positive politeness can achieve and maintain friendly and harmonious relationships with others. This current study also reported that the main character's aim to use a positive strategy in making conversation was to reveal that the speaker and the addressee are cooperatively involved in the relevant activity. As asserted by Hutauruk (2017) that the speaker used included include both Speaker and Addressee in the action because the speaker wanted to state cooperative assumptions and reduce the impact of FTAs itself. The main characters use positive politeness to show friendship and familiarity. So that the atmosphere of the conversation becomes more relaxed. has closeness and no social status distance with the addressee

\subsubsection{Negative Politeness}

Brown, P., \& Levinson (1987) state that negative politeness intends to create distance between speaker and addressee to show respect. Apologizing is one of sub-politeness strategies of negative politeness. The main character included an apology for her imposition to the addressee, where Periwinkle as the addressee was in this context. She was very sorry about the Periwinkles' condition. She did that strategy to minimize the imposition to the addressee, and she felt that she made a mistake, and she wanted to be responsible for his error by asking for an apology. As supported by (Elham et al., 2016), the speaker used an excuse to regret their past mistakes. Other previous studies which supported this study was conducted by (Mu 2015). She investigated the politeness strategy in an English Chinese movie. This study explored the positive and negative politeness strategies and the differences in English and Chinese movie reviewers. This study tried to find alternative reasons for using negative politeness strategy. This finding also reported that the main character put a negative face while refusing the winter woods rule. She did not care about the negative face, which will be brought by addressee because she felt desperate, and she did not want to be separated again with her sister, Periwinkle. This strategy is used by the main character to motivate the movie characters to express the act of apologizing. Therefore, using negative politeness strategy may lead to avoiding the imposition towards the addressee.

\subsubsection{Off-Record}

Off-record strategies can occur because utterance is influenced by different contexts of the situation (Yanti, 2017). The politeness strategy of off record used by the main character was incomplete utterances such as extract 15. The utterance of incomplete 
sentences may reflect the strategy of 'off record not very frequently. The speaker used incomplete utterances in her utterances be0cause she wanted to avoid the speaker from imposing while doing FTA. It was applied by using ellipsis and letting the addressee interpret the meaning. The main character used it since she used unclear utterances, and the addressee infers the intended meaning. Niroomand (2012) declares that 'off the record' is a strategy where the speaker used ambiguous or unclear utterances that the addressee infers the intended meaning. However, off-record using uncomplete utterance should interpret the meaning of the language. This strategy was also used by the main character to avoid actions or behaviours that can cause embarrassment to the interlocutor. In communicating, the main character also always keeps the face to respect the interlocutor joint in communicating (Brown, P., \& Levinson, 1987).

\subsection{The Function of Politeness Strategy}

To find out the function of the politeness strategy, Brown and Yule's theory was applied. They have declared two functions in the language (Brown \& Yule, 1983). The first function is the transactional view, and the second one is the interactional view. This study revealed 29 data that use a transactional view and 10 data from the interactional perspective. The highest frequency data of the function of politeness strategy was the transactional view. The percentage of the Transactional view was $74.4 \%, 25.6 \%$ interactional one.

\subsubsection{Transactional View}

The example of a transactional view is TB/BR/06; "It's getting warmer, you should get back to the winter. " In this session, Tinker Bell deliver critical information for Periwinkle that temperature in pixie hollow was getting warmer. That was why she must leave pixie hollow and come back to the winter. The transactional view calls the message that contains in this utterance. Based on the analysis, Tinker Bell mostly used a transactional view because she wanted to deliver the critical message to addressee where that information must understand by the addressee. As supported by Brown $\&$ Yule (1983), the transactional view is a function that expresses the message's content. If the message is not delivered clearly, it will happen unexpectedly for both the speaker and addressee.

\subsubsection{Interactional View}

Interaction in communicating focuses on two-way communication processes, speakers, and interlocutor talks (Schramm, 1997). It indicates a form of interactional view.

Meanwhile, the interactional view of findings in his study may indicate, such as in extract 19. The main said, "Great!" to friends. It did not mean that she was revealing something big or comprehensive, but she wanted to show that she was pleased when her friends helped her. As stated by (Brown \& Yule,1983), the interactional view was used to build up and maintain the relation between speaker and addressee without any specific messages such as in the transactional view. And it can be stated that a critical element of interaction in communication is feedback or responses to messages 
(Richard \& Lynn, 2018). The main character used interactional view because she wanted her relationships with her friends either by making her friends appreciate their coming and making them comfortable.

\section{CONCLUSION}

Under the framework of Brown and Levinson's politeness strategy theory, this research explored the types, function of politeness strategy, and the way of politeness strategy applied by the main character in the Tinker Bell: Secret of The Wings movie. The findings showed the highest frequency was positive politeness with $51.3 \%$. The substrategies of the positive politeness were 'offering something to $\mathrm{H}^{\prime}$ in 1 datum, using in-group identity marker in 4 data, slang in 1 datum, avoiding disagreement in 2 data, exaggerating in 2 data, including both $\mathrm{S}$ and $\mathrm{H}$ in 8 data, repetition in 1 data, and requesting in 1 datum. Thus, bald on-record has $33.3 \%$ frequency with the sub-strategy showing disagreement in 3 data, which uses the imperative form in 7 data, giving suggestions/advice in 2 data, the condition in which requesting one datum, and. Meanwhile, negative politeness and off the record has the same frequency with $7.7 \%$. The sub-strategy of negative politeness found that apologizing in 2 data and being indirect one datum and for off-record only one sub-strategy with 3 data, namely being incomplete. The researcher investigated the function of politeness strategy by using Brown and Yule theory. The findings showed that the main character's dominant function was a transactional view with a $74,4 \%$ frequency. Thus, the interactional view has $25,6 \%$.

This research has implications on using politeness strategies of a language in communication aspects for the community. The researchers suggest that further researchers use other theories in Sociopragmatics. This theory can be used to analyze the strategy of politeness in their different areas of study, such as analysis of discourse criticism with sociopragmatic approaches.

\section{REFERENCES}

Abbas, N. F. (2013). Positive Politeness \& Social Harmony in Literary Discourse. International Journal of Applied Linguistics \& English Literature, 2(3), 186-195. https://doi.org/10.7575/aiac.ijalel.v.2n.3p.186

Achmad, S. (2012). Strategi Kesopanan Berbahasa Masyarakat Bugis Pinrang Provinsi Sulawesi Selatan. Bahasa Dan Seni, 40(1), 1-13.

Adel, S. M. R., Davoudi, M., \& Ramezanzadeh, A. (2016). A qualitative study of politeness strategies used by Iranian EFL learners in a class blog. Iranian Journal of Language Teaching Research, 4(1), 47-62.

Ary, D. Jacobs, L. C., \& Sorensen, C. (2010). Introduction to research in education (8th ed.). Belmont: Wadsworth Cengage Learning.

Blackledge, A., Creese, A., \& Hu, R. (2016). The structure of everyday narrative in a 
city market: An ethnopoetics approach. Journal of Sociolinguistics, 20(5), 654676. https://doi.org/10.1111/josl.12213

Bogdan, R.C. \& Biklen, S. . (1982). Qualitative Research of Education: An Introduction to Theory and Methods. Boston: Allyn and Bacon.

Brown, P., \& Levinson, S. (1987). Politeness Universal in Language Usage. Cambridge: Cambridge University Press.

Brown, G., \& Yule, G. (1983). Introduction: Linguistic forms and functions. In Discourse analysis (2nd ed). https://doi.org/10.1017/CBO9780511805226.003

Creswell, J. W. (2007). Qualitative Inquiry and Research Design: Choosing Among Five Approaches. (2nd ed.). United States of America: Sage Publication.

Cutting, J. (2002). Pragmatics and Discourse: A Resource Book for Students. London: Routledge.

Dowlatabadi, H., Mehri, E., \& Tajabadi, A. (2014). Politeness Strategies in Conversation Exchange: The Case of Council for Dispute Settlement in Iran. Procedia - Social and Behavioral Sciences, 98, 411-419. https://doi.org/10.1016/j.sbspro.2014.03.434

Elham, A., Farinas Shirani, B., \& Hadi, S. (2016). Apologies as Politeness Strategies Expressed by Characters in "Revolutionary Road" Movie. 5(6). https://doi.org/10.7575/aiac.ijalel.v.5n.6p.134

Hutauruk, B. S. (2017). Politeness Strategies On " Harry Potter And The Half-Blood Prince " Movie. Journal of English Language and Culture, 7(2), 48-56.

Hymes, D. (1996). Ethnography, Linguistics, Narrative Inequality: Toward an Understanding of Voice. London: Taylor \& Francis.

Karimkhanlooei, G., \& Vaezi, N. (2017). Politeness strategies in written communications: the issue of Iranian EFL learners. Journal of Language and Cultural Education, 5(3), 108-126. https://doi.org/10.1515/jolace-2017-0031

Leech, G. (1983). Principles of Pragmatics. London: Longman Group Limited.

Lestari, P., \& Prayitno, J. (2016). Strategi Dan Skala Kesantunan Tindak Direktif Mahasiswa Riau Di Lingkungan Masyarakat Berlatar Belakang Budaya Jawa. Jurnal Penelitian Humaniora, 17, 135-148. https://doi.org/10.15294/ijeces.v3i1.9469

Lyons, J. (1996). Semantics, Volume I. Cambridge: Cambridge University Press.

Manik, S., \& Hutagaol, J. (2015). An Analysis on Teachers' Politeness Strategy and Student's Compliance in Teaching-Learning Process at SD Negeri 024184 Binjai Timur Binjai -North Sumatra-Indonesia. English Language Teaching, 8(8), 152170. https://doi.org/10.5539/elt.v8n8p152

Manurung, R. T. (2010). Model Gaya Bertutur Penghuni di Apartemen Bersubsidi :Suatu kajian Sosiopragmatik “Alih Kode." Sosioteknologi, 20, 923933.

Mirzaei, A ., Roohani, A., Esmaeli, M. (2012). Exploring Pragmalinguistic and Sociopragmatic Variability in Speech Act Production of L2 Learners and Native Speakers. The Journal of Teaching Language Skills (JTLS), 4(3), 79-102.

$\mathrm{Mu}$, Y. (2015). The Application of Politeness Strategies in English and Chinese Movie 
Reviews. International Journal of English Linguistics, 5(6), 105. https://doi.org/10.5539/ijel.v5n6p105

Ndanu, Mwaniki Celestine \& Syombua, M. J. (2015). Mixed Methods Research: The Hidden Cracks of the Triangulation Design. General Education Journal, 4(September), 68-75.

Nihayati, Z. (2018). Politeness Strategies Performed by Male and Female Characters in Roland. Language Horizon, 06(1), 40-49.

Niroomand, M. (2012). An Exploration of Upper-intermediate Iranian EFL learners' Perception of Politeness Strategies and Power Relation in Disagreement. English Language Teaching, 5(10), 180-192. https://doi.org/10.5539/elt.v5n10p180

Nurjamily, W. O. (2015). Kesantunan Berbahasa Indonesia Dalam Lingkungan Keluarga (Kajian Sosiopragmatik). Jurnal Humanika, 3(15).

Priscilia, Y. M., Charlina, \& Rahman, E. (n.d.). Kesantunan berbahasa dalamnovel 99 cahaya di langit eropakarya hanum salsabiela raisdanrangga almahhendra. (1), $1-15$.

Putri, I. G. A. V. W. (2017). Politeness Strategies Employed by the Trainers in Room Division Department Bapepar Nusa Dua. Lingual, 8(1), 87-114.

Richard, W., \& Lynn, T. (2018). Introducing Communication Theory: Analysis and Application 6th Edition (6th ed.). New-York: McGraw-Hill Education.

Rosari, M. (2016). Politeness Strategies Applied by the Characters of The Great Debaters Movie. LLT Journal, 19(1), 19-33.

Rosari, M. (2017). Politeness Strategies Applied by the Characters of The Great Debaters Movie. Language and Language Teaching Journal, 19(01), 19-33. https://doi.org/10.24071/11t.2016.190103

Ryabova, M. (2015). Politeness Strategy in Everyday Communication. Procedia Social and Behavioral Sciences, 206(November), 90-95.

https://doi.org/10.1016/j.sbspro.2015.10.033

Schramm, W. L. (1997). Study in America: A Personal Memoir. Sage Publication, Inc.

Tobing, beslin L. (2017). Kesantunan Berbahasa Dalam Film Perahu Kertas 1\&2: Kajian Pragmatik. Repository FKIP Universitas Jambi, 1-18.

Wang, Y. (2010). Analyzing Hedges in Verbal Communication : An Adaptation-Based Approach. English Language Teaching, 3(3), 120-124.

Wijayanto, A., Laila, M., Prasetyarini, A., \& Susiati, S. (2013). Politeness in Interlanguage Pragmatics of Complaints by Indonesian Learners of English. English Language Teaching, 6(10), 188-201. https://doi.org/10.5539/elt.v6n10p188

Yanti, R. (2017). An Analysis of Off Record Strategies Reflecting Politeness Implicature in " Oprah Winfrey Show." 1.

Yaqubi, Yaqubi, M., Author, C., Rose, W., Abdul, E., \& Ph, R. (2012). Gender-linked Choice of Politeness Strategies Applied to Translation of Persian Facethreatening Acts into English. International Journal of Applied Linguistics \& English Literature, 1(7), 66-79. https://doi.org/10.7575/ijalel.v.1n.7p.66 